\title{
Ureaplasma urealyticum causing persistent urethritis in a patient with hypogammaglobulinaemia
}

\author{
D TAYLOR-ROBINSON,* P M FURR,* AND A D B WEBSTER $\dagger$ \\ From the Divisions of *Sexually Transmitted Diseases and $\dagger$ Immunological Medicine, MRC Clinical Research \\ Centre, Harrow, Middlesex
}

SUMMARY Ureaplasma urealyticum organisms (ureaplasmas) were isolated in large numbers (up to $10^{8}$ colour changing units $(\mathrm{ccu}) / \mathrm{ml}$ ) over a period of four years from the urethra of a man with hypogammaglobulinaemia and non-gonococcal urethritis. Elimination of Mycoplasma hominis by antibiotic treatment early in the course of the urethritis did not diminish the severity of his condition, which indicated that this mycoplasma was not a cause. Courses of treatment with tetracyclines, spectinomycin, erythromycin, rosaramicin, and clindamycin on each occasion reduced the numbers of ureaplasmas isolated from the urethra and the severity of disease. The organisms were not eliminated, however, sometimes due to the development of antibiotic resistance, and the urethritis recurred. Though netilmicin was not particularly effective in vitro, it was effective clinically, the disease resolving and the organisms disappearing for five months. Recurrence of urethritis, accompanied by epididymitis, was associated this time with the recovery of a different (tetracycline sensitive) ureaplasma strain; the urethritis and epididymitis were treated successfully with a combination of netilmicin and doxycycline. The administration of ureaplasma antiserum did not seem to be instrumental in eradicating the ureaplasmas. The various antibiotics had a greater influence on the mycoplasmas in the urethra than on those in the throat and joints, perhaps because the antibiotics were concentrated in the urogenital tract. The close association between the occurrence of urethritis and the ureaplasmas suggests strongly that they were responsible for it.

\section{Introduction}

The role of genital mycoplasmas, particularly Ureaplasma urealyticum organisms (ureaplasmas), in causing non-gonococcal urethritis (NGU) and other diseases has been discussed on numerous occasions. ${ }^{1-6}$ The results of several studies provide evidence that ureaplasmas cause some cases of NGU, though these data are less convincing than those for Chlamydia trachomatis. Conversely, evidence for the implication of ureaplasmas in other diseases is weak. The special conditions provided by hypogammaglobulinaemia, however, enable these organisms and other mycoplasmas to invade and cause septic arthritis, ${ }^{67}$ and we have drawn attention already to the occurrence of chronic cystitis and urethritis associated with the isolation of genital mycoplasmas in patients with

Address for reprints: Dr D Taylor-Robinson, Division of Sexually Transmitted Diseases, MRC Clinical Research Centre, Watford Road, Harrow, Middlesex HA1 3UJ

Accepted for publication 18 March 1985 hypogammaglobulinaemia. ${ }^{8}$ We present now a more detailed account of the clinical and microbiological events that occurred in a patient with hypogammaglobulinaemia who developed NGU. These details suggest strongly that $U$ urealyticum was a cause of the urethritis.

\section{Patient and methods}

Hypogammaglobulinaemia had been diagnosed in the first three years of the patient's life. In 1977, when 18 years old, he developed ureaplasmal septic arthritis of a knee joint, which resolved completely after treatment with tetracyclines. ${ }^{9}$ He presented next in October 1979 with dysuria and a urethral discharge. During the following four years he was examined clinically and microbiologically on numerous occasions, as shown in table $\mathrm{I}$.

We examined urethral smears for polymorphonuclear leucocytes (PMNL) and diagnosed NGU if there were $\geqslant 5$ PMNL per high power ( $\times 600$ magnification) microscope field. Gram negative intracellular diplococci were not seen, and the 
absence of Neisseria gonorrhoeae was confirmed by culture. We tested urethral specimens (taken with nasopharyngeal swabs; MW 142, Medical Wire and Equipment Co, Corsham, Wiltshire, England) and on some occasions midstream urine samples for ureaplasmas and Mycoplasma hominis using media and methods described previously. ${ }^{10}$ Briefly, swabs were agitated and expressed in $1.8 \mathrm{ml}$ of liquid medium. This was regarded as a 10 -fold dilution and was diluted serially in 10-fold steps so that the numbers of organisms, expressed as colour changing units (ccu), could be estimated." Some specimens were examined also for $C$ trachomatis organisms (chlamydiae) using cycloheximide treated McCoy cells ${ }^{12}$ and for Bacteroides ureolyticus and Gardnerella vaginalis using procedures and media described before. ${ }^{1314}$ In addition, throat swabs taken sporadically were examined for ureaplasmas and $M$ hominis.

The sensitivity of ureaplasmas and $M$ hominis to various antibiotics was tested in vitro by a broth dilution technique described in detail previously. ${ }^{15} 16$

\section{Results}

ASSOCIATION BETWEEN URETHRITIS AND MICROORGANISMS ISOLATED FROM THE URETHRA

Table I presents chronologically the clinical and microbiological events. The original episode of dysuria and urethral discharge did not respond to a 10 day course of co-trimoxazole or tetracycline for three days. The urine was sterile on routine bacteriological testing, and chlamydiae were not recovered from urethral swabs. Ureaplasmas $\left(10^{6}\right.$ colour changing units $(\mathrm{ccu}) / \mathrm{ml}$ ) and $M$ hominis organisms $\left(10^{7} \mathrm{ccu} / \mathrm{ml}\right)$ were, however, isolated from the urine. A seven day course of intramuscular spectinomycin $(2 \mathrm{~g}$ every eight hours) combined with intravenous tetracycline produced some clinical improvement with a reduction in the number of organisms, but relapse associated with the isolation of an even larger number of ureaplasmas and a temporary failure to recover $M$ hominis suggested that ureaplasmas but not $M$ hominis might be causing the urethritis. During a seven day course of erythromycin (600 mg four times a

TABLE I Episodes of urethritis, isolation of micro-organisms, and courses of treatment in a patient with hypogammaglobulinaemia

\begin{tabular}{|c|c|c|c|c|}
\hline \multirow[b]{2}{*}{ Date } & \multirow{2}{*}{$\begin{array}{l}\text { Severity of } \\
\text { urethritis* }\end{array}$} & \multicolumn{2}{|c|}{ Urethral isolation $(\mathrm{ccu} / \mathrm{ml})$ of: } & \multirow[b]{2}{*}{ Treatment } \\
\hline & & Ureaplasma urealyticum & Mycoplasma hominis & \\
\hline November $1979 \dagger$ & + & $10^{6}$ & $10^{7}$ & $\begin{array}{l}\text { Tetracycline } \\
\text { Spectinomycin }\end{array}$ \\
\hline $\begin{array}{l}\text { December } 1979 \\
\text { January } 1980 \dagger\end{array}$ & $\stackrel{ \pm}{+}+$ & $\geqslant 10^{3}$ & $10^{2}$ & \\
\hline $\begin{array}{l}\text { January } 1980 \\
\text { February } 1980 \ddagger\end{array}$ & $\stackrel{ \pm}{+}+$ & $10^{7}$ & $\geqslant \begin{array}{l}10^{5} \\
10^{4}\end{array}$ & Erythromycin \\
\hline March 1980 & \pm & $10^{4}$ & $10^{2}$ & Rosaramin \\
\hline $\begin{array}{l}\text { April } 1980 \\
\text { October } 1980 \\
\text { April } 1981 \\
\text { December } 1981 \\
\text { Đecember } 1982\end{array}$ & $\begin{array}{l}++ \\
++ \\
++ \\
++ \\
++\end{array}$ & $\begin{array}{r}10^{7} \\
10^{7} \\
\geqslant 10^{8} \\
10^{7} \\
10^{7}\end{array}$ & & NUSal antiliti \\
\hline April 1983 & ++ & $10^{6}$ & & Erythromycin \\
\hline $\begin{array}{l}\text { May } 1983 \\
\text { June 1983† }\end{array}$ & $\begin{array}{l}+ \\
\pm\end{array}$ & $\begin{array}{l}10^{3} \\
10^{4}\end{array}$ & & Clindamycin \\
\hline August 1983 & + & $10^{8}$ & & Ciprofloxacin \\
\hline $\begin{array}{l}\text { September } 1983 \\
\text { November } 1983 \\
\text { February } 1984 \dagger\end{array}$ & $\begin{array}{l}- \\
\overline{+}\end{array}$ & $10^{6} \S$ & & Netilmicin \\
\hline $\begin{array}{l}\text { April } 1984 \\
\text { May } 1984 \\
\text { July } 1984 \\
\text { December } 1984\end{array}$ & $\begin{array}{l}- \\
- \\
-\end{array}$ & & & Netilmicin \\
\hline
\end{tabular}

$\mathrm{ccu}=$ Colour changing units.

*Urethritis severe $(++)$, moderate $(+)$, mild $( \pm)$, and absent $(-)$ based on clinical and cellular criteria.

†Negative culture for Chlamydia trachomatis.

$\ddagger$ Povidone-iodine irrigation given before rosaramicin (see text).

$\S$ Sensitive to tetracycline.

INegative cultures for Bacteroides ureolyticus and Gardnerella vaginalis. 
day intravenously) in January 1980 the urethral discharge diminished and ureaplasmas were not isolated, though $M$ hominis was still present, which suggested again that $M$ hominis was not a cause of the urethritis. Two weeks later the condition relapsed and ureaplasmas were isolated again in large numbers from the urine and urethra. Bladder irrigation with $1 \%$ povidone-iodine was undertaken on three occasions, but this did not improve the symptoms or eradicate the ureaplasmas.

In February and March 1980 the patient was given rosaramicin (500 mg four times a day by mouth). Within four days the urethral discharge disappeared, the urine became clear, and 1000-fold fewer ureaplasmas and 100-fold fewer $M$ hominis organisms were isolated. His symptoms returned within three days when the drug was discontinued for a week, however, and a further two week course of rosaramicin produced no relief, probably because of the emergence of antibiotic resistant ureaplasmas, which were isolated from both the urine and urethra. $M$ hominis was not recovered at this time or subsequently, which indicated that it was not implicated in the disease process.

On eight occasions (not all shown in table I) during the next two years the patient was found to have frank urethritis ( $\geqslant 15$ PMNL/high power field) and ureaplasmas were isolated in large numbers $\left(10^{7}-\right.$ $\geqslant 10^{8} \mathrm{ccu} / \mathrm{ml}$ ) each time. Treatment with clindamycin (300 mg four times a day by mouth) began in May 1983 and continued for three months. This reduced the number of ureaplasmas 10000 -fold and diminished the severity of the disease. However, despite the intravenous administration of immunoglobulin
(Sandoglobulin; Sandoz, Feltham, Middlesex, England) twice a week during June and July 1983 and a two week course of ciprofloxacin $(500 \mathrm{mg}$ twice a day by mouth), the organisms were not eliminated, and they had increased considerably in number by August. A two month course of netilmicin (180 mg twice a day intramuscularly) was then instituted despite its only moderate activity in vitro. This eradicated the ureaplasmas, and the urethritis resolved.

Between early January and mid-October 1984 the patient received $500 \mathrm{ml}$ of goat hyperimmune ureaplasma serum in an effort to eradicate ureaplasmas from other sites (joints and abscesses). The administration of antiserum did not prevent the recurrence of urethritis accompanied by a right sided epididymitis in February 1984. This was associated with further isolation of ureaplasmas from the urethra that, this time, were tetracycline sensitive. The patient was treated again with netilmicin ( $180 \mathrm{mg}$ twice a day) and with doxycycline (200 mg daily), both for one month. This regimen proved successful clinically and microbiologically, and the organisms had not reappeared in the urethra in the subsequent 12 months.

ANTIBIOTIC SENSITIVITY OF MICRO-ORGANISMS ISOLATED FROM THE URETHRA

Table II shows the susceptibilities of the ureaplasmas and $M$ hominis isolated from the urethra of the patient at various stages to most of the antibiotics considered. It may be seen that at the outset (in November 1979) the ureaplasmas were partially resistant to the tetracyclines, the final minimum inhibitory concentration (MIC) being much higher than the

TABLE II Antibiotic susceptibility of micro-organisms isolated from a patient with hypogammaglobulinaemia

\begin{tabular}{|c|c|c|c|c|c|c|}
\hline \multirow[b]{3}{*}{ Date } & \multirow{3}{*}{$\begin{array}{l}\text { Antibiotic } \\
\text { administered } \\
\text { to patient }\end{array}$} & \multirow{3}{*}{$\begin{array}{l}\text { Antibiotic } \\
\text { tested also } \\
\text { in vitro }\end{array}$} & \multicolumn{4}{|c|}{ Minimum inhibitory concentration $(M I C)(m g / l)$ for: } \\
\hline & & & \multicolumn{2}{|c|}{ Ureaplasma urealyticum } & \multicolumn{2}{|c|}{ Mycoplasma hominis } \\
\hline & & & Initial MIC & Final MIC & Initial MIC & Final MIC \\
\hline \multirow{5}{*}{$\begin{array}{l}\text { November } 1979 \\
\text { January } 1980 \\
\text { March } 1980 \\
\text { April } 1980\end{array}$} & $\begin{array}{l}\text { Tetracycline } \\
\text { Spectinomycin }\end{array}$ & & $\begin{array}{l}0.1 \\
0.01\end{array}$ & $\begin{array}{ll}31 \\
0.1\end{array}$ & $\begin{array}{l}0.001 \\
0.01\end{array}$ & $\begin{array}{l}1 \\
0.03\end{array}$ \\
\hline & $\begin{array}{l}\text { Erythromycin } \\
\text { Rosaramicin } \\
\text { Rosaramicin }\end{array}$ & & $\begin{array}{l}0.01 \\
0.0004 \\
4\end{array}$ & $\begin{array}{l}0.1 \\
0.0004 \\
31\end{array}$ & $\frac{250}{0.0004}$ & $\begin{array}{l}500 \\
0.0004\end{array}$ \\
\hline & & Rosoxacin & $0 \cdot 1$ & 0.25 & * & * \\
\hline & & Gentamicin & 1000 & $>1000$ & * & * \\
\hline & & Streptomycin & 250 & 1000 & * & * \\
\hline \multirow{4}{*}{$\begin{array}{l}\text { April } 1983 \\
\text { May } 1983\end{array}$} & $\begin{array}{l}\text { Erythromycin } \\
\text { Clindamycin }\end{array}$ & & $\begin{array}{l}\text { NT } \\
0.0004\end{array}$ & $\begin{array}{r}\text { NT } \\
0.25\end{array}$ & * & * \\
\hline & & Tetracycline & 125 & $>1000$ & * & * \\
\hline & & Spectinomycin & 8 & 500 & * & * \\
\hline & Ciprofloxacin & Rosoxacin & & 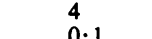 & * & * \\
\hline $\begin{array}{l}\text { August } 1983 \\
\text { September } 1983\end{array}$ & Netilmicin & & $\begin{array}{l}0 \cdot 03 \\
2\end{array}$ & $\begin{array}{l}0 \cdot 1 \\
8\end{array}$ & * & * \\
\hline \multirow{2}{*}{ February 1984} & Netilmicin & & 1 & $125^{\circ}$ & * & * \\
\hline & Doxycycline & Tetracycline & $<0.0004$ & 8 & * & * \\
\hline
\end{tabular}

${ }^{*} M$ hominis not isolated and therefore not tested.

NT $=$ not tested. 
initial one. The activity of erythromycin in vitro correlated with its initial effectiveness in vivo but, as noted in table $I$, the condition relapsed and large numbers of ureaplasmas were recovered. Both ureaplasmas and $\boldsymbol{M}$ hominis were very susceptible to rosaramicin. The former, however, developed resistance rapidly, which was indicated not only by the result of the in vitro test but also by the recovery of large numbers of ureaplasmas from the urethra, whereas $\boldsymbol{M}$ hominis was eliminated. Clindamycin was active also against ureaplasmas in vitro, but again was effective for a short period only in vivo. Though netilmicin was not the most active drug in vitro, it was effective in eliminating the ureaplasmas. It was clear also that the ureaplasmas isolated after the successful course of netilmicin occurred as a result of reinfection because, unlike those isolated previously, they were found to be tetracycline sensitive.

ISOLATION OF MICRO-ORGANISMS FROM THE THROAT

Attempts to isolate ureaplasmas and $M$ hominis from the throat were made on nine occasions. Table III shows the results compared with those of attempts to isolate the organisms from the urethra at the same time. A reduction in the number of organisms in the urethra or their elimination from this site by antibiotic treatment was not accompanied by an equivalent reduction in the number of organisms in the throat. Netilmicin was successful in eradicating ureaplasmas from the urethra but did not eliminate them from the throat, though apparently it was successful in eliminating $M$ hominis from this site.

TABLEIII Comparative isolation of Ureaplasma urealyticum and Mycoplasma hominis from the throat and urethra

\begin{tabular}{|c|c|c|c|c|}
\hline \multirow[b]{2}{*}{ Date } & \multicolumn{2}{|c|}{$\begin{array}{l}\text { U urealyticum } \\
\text { (ccu/ml) isolated } \\
\text { from: }\end{array}$} & \multicolumn{2}{|c|}{$\begin{array}{l}\text { Mhominis } \\
\text { (ccu/ml) isolated } \\
\text { from: }\end{array}$} \\
\hline & Throat & Urethra & Throat & Urethra \\
\hline $\begin{array}{l}\text { November } 1979 \\
\text { January } 1980 \\
\text { January } 1980 \\
\text { February } 1980 \\
\text { April } 1980 \\
\text { December } 1982 \\
\text { June } 1983 \\
\text { November } 1983 \\
\text { April } 1984\end{array}$ & $\begin{array}{l}10^{3} \\
10^{4} \\
10^{4} \\
10^{6} \\
10^{4} \\
* \\
10^{2} \\
10^{3} \\
10^{2}\end{array}$ & $\begin{array}{r}10^{6} \\
\geqslant 10^{8} \\
10^{7} \\
10^{7} \\
10^{7} \\
10^{4}\end{array}$ & $\begin{array}{r}10^{4} \\
10^{5} \\
\geqslant 10^{5} \\
10^{5} \\
10^{5} \\
{ }^{*} \\
10^{2}\end{array}$ & $\begin{array}{r}10^{7} \\
\geqslant 10^{5} \\
10^{4}\end{array}$ \\
\hline
\end{tabular}

$\mathrm{ccu}=$ Colour changing unit .

*Specimen positive but not titrated.

\section{Discussıon}

Several features of this case indicate that the ureaplasmas were the cause of the persistent urethritis.
Firstly, other micro-organisms, such as $C$ trachomatis, $B$ ureolyticus, and $M$ genitalium, were not isolated. The latter two were not sought originally because the possible role of $B$ ureolyticus in NGU had not been appreciated then, ${ }^{17}$ and $M$ genitalium had not been discovered. ${ }^{18}$ M hominis was isolated originally, but its presence in the absence of disease after erythromycin treatment, and its absence later in the presence of disease indicate that it was not associated with the pathogenesis of the urethritis. Secondly, large numbers of ureaplasmas were isolated consistently from the urethra except when they had been reduced in number by antibiotic treatment. Indeed, the third feature is the relation established between the numbers of organisms isolated and the disease as a result of antibiotic treatment. Antibiotics that reduced the number of organisms or apparently eliminated them were those that also improved the disease clinically; return of the disease was associated with a return of the organisms. This finding was similar to that recorded by Shepard, who saw the reappearance of NGU and ureaplasmas after apparently successful treatment of men with sub-optimum doses of tetracycline: ${ }^{19}$ unfortunately, the involvement of chlamydiae was not ruled out in his studies.

The same ureaplasma strain, serotype 2 , seems likely to have been involved almost throughout the episode of persistent urethritis in this patient with hypogammaglobulinaemia. The organisms recurred in the urethra after antibiotic treatment probably because they were never eliminated from the urogenital tract, perhaps residing in the prostate from where they were able to recolonise. The failure of the various antibiotics to eliminate the ureaplasmas may have been due to the large number of organisms present, their inability to kill the organisms, and the development of resistance to some of these antibiotics, particularly rosaramicin. ${ }^{16}$ Netilmicin was unusual in two respects. Firstly, it was found to be not the most effective antibiotic in vitro and yet it was successful in eliminating the ureaplasmas from the urogenital tract, and secondly, they did not become particularly resistant to it. The isolation of ureaplasmas once again, in association with a further episode of NGU and epididymitis, was due almost certainly to exogenous reinfection because the organisms were tetracycline sensitive on this occasion in contrast to the resistance noted previously.

The difficulty of eliminating mycoplasmas, particularly the ureaplasmas, from the urogenital tract was exceeded by the difficulty of eliminating them from the throat and joints. The reasons are not clear, but the likelihood of lower antibiotic concentrations in the throat and joints compared with those in the urogenital tract may have been an important factor.

There was repeated failure to treat the urethritis 
successfully until netilmicin was used. This failure may be explained not only by the factors mentioned previously, including the development of antibiotic resistance, but also by the failure of the immune system to eliminate either antibiotic resistant or sensitive ureaplasmas after treatment, which is not likely to occur in immunocompetent patients. Intravenous administration of immunoglobulin and urethral irrigation with immunoglobulin were reported as being instrumental in curing the disease in another hypogammaglobulinaemic patient with refractory ureaplasma positive NGU. ${ }^{20}$ We have, however, commented previously on the difficulty of assessing the role of the immunoglobulin in the successful treatment of that particular patient. ${ }^{21}$ In the case we describe here, though ureaplasma antiserum was given intermittently over a prolonged period, insufficient antibody seems to have found its way into the urine or tissues of the urogenital tract to affect the ureaplasmas. Whatever mode of treatment is chosen, however, early success appears to be important in immunodeficient patients not only to prevent chronic urogenital tract disease but because the infected urogenital tract can provide a source of organisms for haematogenous spread to other anatomical sites, such as the joints. Indeed, the patient we describe experienced several bouts of septic arthritis, apart from the one that brought him to attention originally, in which ureaplasmas were isolated from the joints.

We thank Mr E A R Fontaine and Miss Y Boustouller for their help.

\section{References}

1. Taylor-Robinson D. The possible role of ureaplashas in nongonococcal urethritis. In: Hobson D, Holmes KK, eds. Nongonococcal urethritis and related infections. Washington DC: American Society for Microbiology, 1977;30-7.

2. Taylor-Robinson D, McCormack WM. The genital mycoplasmas. N Engl J Med 1980;302:1003-10.

3. Taylor-Robinson D, Csonka GW. Laboratory and clinical aspects of mycoplasma infections of the human genitourinary tract. In: Harris JRW, ed. Recent advances in sexually transmitted diseases. London: Churchill Livingstone, 1981:151-86.
4. Taylor-Robinson D. The role of mycoplasmas in nongonococcal urethritis: a review. Yale J Biol Med 1983;56:53743.

5. Taylor-Robinson D. Mycoplasma infections of the human urogenital tract with particular reference to non-gonococcal urethritis. Ann Microbiol (Paris) 1984;135A:129-34.

6. Taylor-Robinson D. Ureaplasmas as a cause of disease in man and animals: fact or fancy? Isr J Med Sci 1984;20:843-7.

7. Taylor-Robinson D, Thomas BJ, Furr PM, Keat AC. The association of Mycoplasma hominis with arthritis. Sex Transm Dis 1983;10:341-4.

8. Webster ADB, Taylor-Robinson D, Furr PM, Asherson GL Chronic cystitis and urethritis associated with ureaplasmal and mycoplasmal infection in primary hypogammaglobulinaemia. Br J Urol 1982;54:287-91.

9. Webster ADB, Taylor-Robinson D, Furr PM, Asherson GL. Mycoplasmal (ureaplasma) septic arthritis in hypogammaglobulinaemia. Br Med J 1978;i:478-9.

10. Taylor-Robinson D, Martin-Bourgon C, Watanabe T, Addey JP. Isolation of T-mycoplasmas from dogs and squirrel monkeys: biological and serological comparison with those isolated from man and cattle. J Gen Microbiol 1971;68:97-107.

11. Taylor-Robinson D, Purcell RH. Mycoplasmas of the human urogenital tract and oropharynx and their possible role in disease: a review with some recent observations. Proc Roy Soc Med 1966;59:1112-6.

12. Evans RT, Taylor-Robinson D. Comparison of various McCoy cell treatment procedures used for detection of Chlamydia trachomatis. J Clin Microbiol 1979;10:198-201.

13. Fontaine EA, Taylor-Robinson D. Evaluation of liquid transport media for the isolation of anaerobic bacteria: relevance to genital tract specimens. J Infect 1981;3:360-9.

14. Totten PA, Amsel R, Hale J, Piot P, Holmes KK. Selective differential human blood bilayer media for isolation of Gardnerella (Haemophilus) vaginalis. J Clin Microbiol 1982;15:141-7.

15. Taylor-Robinson D. Mycoplasmas of various hosts and their antibiotic sensitivities. Postgrad Med $J$ 1967;43 suppl:100-4

16. Taylor-Robinson D, Furr PM. The static effect of rosaramicin on Ureaplasma urealyticum and the development of antibiotic resistance. J Antimicrob Chemother 1982;10:185-91.

17. Fontaine EA, Taylor-Robinson D, Hanna NF, Coufalik ED. Anaerobes in men with urethritis. British Journal of Venereal Diseases 1982;58:321-6.

18. Tully JG, Taylor-Robinson D, Cole RM, Rose DL. A newly discovered mycoplasma in the human urogenital tract. Lancet 1981;i:1288-91.

19. Shepard MC. Quantitative relationship of Ureaplasma urealyticum to the clinical course of nongonococcal urethritis in the human male. Les Colloques INSERM 1974;33:375-9.

20. Spelman DW, Bradford D. Intraurethral immunoglobulin in the treatment of non-specific urethritis. British Journal of Veneral Diseases 1984;60:58-9.

21. Taylor-Robinson D, Furr PM, Webster ADB. Case reports of urethritis. British Journal of Venereal Diseases 1984;60:276-7. 